ENTREPRENEURSHIP AND SUSTAINABILITY ISSUES

ISSN 2345-0282 (online) http://jssidoi.org/jesi/

2021 Volume 8 Number 3 (March)

http://doi.org/10.9770/jesi.2021.8.3(20)

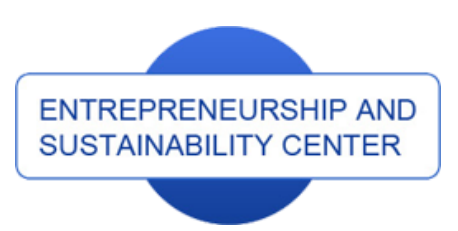

Publisher

$\underline{\text { http://jssidoi.org/esc/home }}$
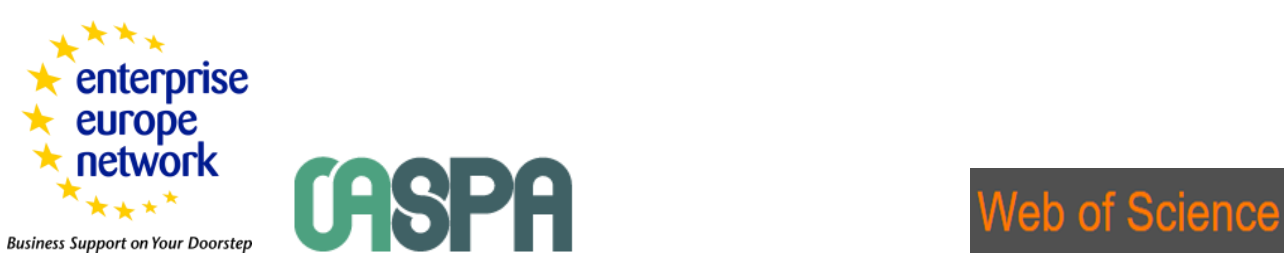

1) Clarivate

\title{
SOCIAL COMPETENCE-BASED PROGNOSTIC POSSIBILITIES OF CREATIVITY EXPRESSION AMONG STUDENTS OF SOCIAL PROFILE
}

\author{
Kristina Samašonok ${ }^{1}$, Agnė Juškevičienė ${ }^{2}$ \\ 1,2 Vilniaus kolegija / University of Applied Sciences, Saltoniškiu Street 58, Vilnius, Lithuania \\ E-mails: ${ }^{1}$ k.samasonok@vvf.viko.lt ; ${ }^{2}$ a.juskeviciene@vvf.viko.lt
}

Received 20 September 2020; accepted 10 January 2020; published 30 March 2021

\begin{abstract}
The article presents a theoretical discussion of peculiarities of creativity and social competence. Creativity expression is analysed on the basis of social competence. The aim of research: to investigate peculiarities of perceived creativity and social competence of students of social profile in Lithuanian higher education schools, to disclose their correlations and to foresee prognostic possibilities of creativity expression on the basis of social competence. The research methodologies: The Questionnaire of Personality Creativity (Petrulis, 1988) was used to investigate the students' perceived creativity according to the subscales of intuition, phantasy, inclination to creativity, inclination to innovation, flexibility, originality, criticality, inversion and childishness. The students' social competence was assessed using the questionnaire of Ullriche, de Muynck (1994) (cf. Lekavičiene, 2001) according to the subscales of general self-confidence, resistance to failures and criticism, ability of expressing feelings, ability of asking for a favour, unyielding, ability of demanding and feeling not guilty. Employing the strategy of quantitative research, the correlations of components of social profile students' perceived creativity and social competence were established. It was also identified that social competence acquires a prognostic meaning to expression of students' creativity. The research results will have a residual value in the scientific discussion about the social competence-based expression of students' creativity.
\end{abstract}

Keywords: social competence; perceived creativity; students of social profile

Reference to this paper should be made as follows: Samašonok, K., Juškevičienè, A. 2021. Social competence-based prognostic possibilities of creativity expression among students of social profile. Entrepreneurship and Sustainability Issues, 8(3), 324-339. http://doi.org/10.9770/jesi.2021.8.3(20)

JEL Codes: A2

\section{Introduction}

Under the influence of requirements imposed by the technological progress and market economy, in the rapidly changing society, at present novice specialists need more than just competences that are based on exclusively professional skills. Seeking to adapt to the requirements of labour market and acquire competitive advantages, a particular emphasis is laid on the person's critical thinking, his/her ability to generate new ideas and to implement 


\section{ENTREPRENEURSHIP AND SUSTAINABILITY ISSUES}

ISSN 2345-0282 (online) http://jssidoi.org/jesi/

2021 Volume 8 Number 3 (March)

http://doi.org/10.9770/jesi.2021.8.3(20)

them, to boldly face new challenges and adapt to constantly changing conditions (Wang et al., 2006). Moreover, self-confidence, communication skills, ability to efficiently participate in social interactions, to work in a team and to foster positive interpersonal relations serve as a factor of social welfare and a driver of innovations (Šinkūniené, 2011) as well as guarantee success in the social environment and professional activity, help to pursue a career and to remain competitive in ever-changing situations (Iždonaitè-Medžiūniené, 2009). Thus, in the context of the rapid development of technologies, information communication technologies and economy and under conditions of social, cultural changes in the society, the individual's creativity and social competence have been acquiring an exceptional significance.

The peculiarities of social competence and creativity and their expression have been a popular research object among researchers in the last several decades. The analysis of research works allows noticing that the main focus is laid on delving into the features of socially competent (Iždonaitè-Medžiūnienė, 2009; Lekavičienė, 2001) and creative (Grakauskaitė - Karkockienė, 2010; Torrance, 1986; Jaskyte, Taylor, Smariga, 2009; Sternberg, 2006) personality. The person's creativity as one of the key features in the labour market is emphasised (Rakauskaite, 2014; Vaičiūnienè, Mažeikienè, 2014). Other researchers (Hemlin, Allwood and Martin, 2008; Grakauskaitė Karkockiene, 2010) allocated more attention to the research on the factors that contribute to manifestations of person's creativity, whereas Malinauskas (2003), Šniras (2005) analysed tendencies, possibilities and problems related to social competence development. Thus, the main focus of researchers is laid on studying features of socially competent and creative personality and distinguishing the factors that result in their manifestation. However, the components of individual's social competence, as some of the factors that influence expression of creativity, have not been exhaustively investigated and in-depth and empirically grounded research studies are few. In such a situation, the links between the components of social competence and perceived creativity as well as their prognostic analysis have been more and more often seen as an important field of scientific research. On the other hand, more comprehensive scientific research conducted applying the regression analysis, which would allow foreseeing social competence-based prognostic possibilities of perceived creativity expression according to separate dimensions in the regression equation, would help to identify if the level of social competence could influence manifestation of person's creativity. It would also be possible to establish the components of person's creativity which can acquire a prognostic meaning for creativity expression as well as to disclose the possibilities for promotion of personal creative potential while developing social competences.

Considering the relevance of the topic, the article reveals the peculiarities of perceived creativity and social competence of social profile students from Lithuanian higher education schools. The correlations of components of creativity and social competence are identified and prognostic possibilities of creativity expression are foreseen.

The research problem is defined through the following questions: what level of perceived creativity and social competence is typical of social profile students from Lithuanian higher education schools? How students' perceived creativity is related to components of social competence? What components of students' social competence can significantly forecast the expression of social profile students' perceived creativity?

The object of research: peculiarities of social competence and perceived creativity of social profile students from Lithuanian higher education schools, correlations and prognostic possibilities of some (dependent) variables on the basis of other (independent) variables.

The goal of research: to investigate the peculiarities of social competence and perceived creativity of social profile students from Lithuanian higher education schools, to reveal their correlations and to foresee social competence-based prognostic possibilities of creativity expression.

The objectives of research:

1. To conduct the analysis of previous research on the analysed topic theoretically substantiating manifestation of creativity on the basis of social competence level.

2. To identify peculiarities of perceived creativity and social competence of social profile students from Lithuanian higher education schools. 


\section{ENTREPRENEURSHIP AND SUSTAINABILITY ISSUES}

ISSN 2345-0282 (online) http://jssidoi.org/jesi/

2021 Volume 8 Number 3 (March)

http://doi.org/10.9770/jesi.2021.8.3(20)

3. To disclose corelations of social competence and perceived creativity.

4. To foresee social competence-based prognostic possibilities of expression of perceived creativity in the regression equation.

\section{Theoretical bacground}

Over the last decades the research studies on the analysis of the phenomenon of creative thinking have increased. Up to now discussions have been held about the qualities that characterise a creative personality and how expression and development of person's creativity are encouraged. On the other hand, more often attention is focused on the fact that person's abilities and skills that manifest themselves in social situations comprise an important indicator foreseeing manifestation of individual's creativity. The researchers allocate their attention to the importance of social competence stressing out the expression of person's creativity. Creative thinking is an important indicator of successful business, which, according to the analysis of scholarly literature, is related to the aspects of social competence. It is important that creativity encourages creation of innovations and their introduction in organisations (Cropley, 2015; Newman et al., 2018). Creativity is also linked to the person's pursuit of mastery, willingness to take risk, independence and tolerance to various approaches (Beaney, 2019; Benea-Popuşoi, Duca, 2021; Chen et al., 2018; Demarin, Derke, 2020; Jahanshahi et al., 2019; Huertas, Pergentino, 2020; Karimi, et al., 2020). The works of others researchers focus on the relationships between creativity and leadership and, at the same time, between person's self-confidence and self-respect (Fonseca et al., 2019; Hughes et al., 2018; Koh et al., 2019; Liu et al., 2020). The research results also show that creativity is predetermined by the confidence in the power of own efficiency in the society (Haase et al., 2018). Selfconfidence as an important element of social competence was highlighted by Sipahi (2018) as well, who emphasized that a creative personality is curious, patient, brave enough to accept changes and innovations as well as to take risk.

Other scholars also recognize that personality self-confidence is an important indicator of predicting a person's creative achievement, propensity to use a variety of methods and techniques, fear of risk-taking, creative and original pursuit of results (Pociute, Isiunaite, 2011; Wolfradt, Pretz, 2001). Thus, researchers' research sees trends in the relationship between self-confidence and creativity: self-confidence as well as the ability to boldly challenge challenges are significantly correlated with a person's more strongly expressed level of creativity.

It can be assumed that the person's self-confidence, his/her confidence in own abilities, perseverance with attaining the set goals disregarding the opinions of others have influence on the expression of person's creativity and is an important indicator of creative activities. Thus, the level of person's social competence is related to the expression of creativity, when next to peculiarities as strengths attributed to a creative personality, such qualities as resourcefulness in case of dissatisfaction with possessed information, originality and critical evaluation of own activities and decisions can be mentioned. Meantime, lack of self-confidence can possibly limit manifestation of person's creativity.

Particularly interesting is the concept of 'dark creativity'. 'Dark creativity' is the use of creative ideas for malevolent actions (Palmer et al. 2020). It is a combination of cognitive abilities and motivational aspects. This article is the first to investigate the impact of power on creativity in an immoral occupational task. (Khan et al. 2020) examined the association between the psychological empowerment of project-based employees and the success of the project. The results concluded that psychological empowerment is directly and indirectly positively linked to project success. Diković and Gregović (2020) study was carried out on a sample of teachers from three counties in the Republic of Croatia. Active learning encourages and develops knowledge, skills and attitudes. Teachers should promote this type of learning from the beginning. 


\section{ENTREPRENEURSHIP AND SUSTAINABILITY ISSUES}

ISSN 2345-0282 (online) http://jssidoi.org/jesi/

2021 Volume 8 Number 3 (March)

http://doi.org/10.9770/jesi.2021.8.3(20)

The researchers acknowledge that a creative personality is characterised with general self-confidence, ability to critically evaluate situations, bravery and independence in decision-making (Petrulyte், 2001), emotionality, nonconformism and ability to defend own rights (Grakauskaitė-Karkockienė, 2010). Csikszentmihalyi (1996) states that a creator, as a mature personality, still possesses certain childish features: sincerity, emotionality, impulsivity and sensitivity. On the other hand, a creative personality is resourceful, autonomous and open to new experience, curious, unconstrained and has inclination to originality, more vivid imagination, fluency of thinking and pursuit of new things. Thus, certain abilities and skills comprise some of the key aspects for creative achievements of personality (Wang' et al., 2019). In the study (Kelemen et al. 2020) the relationship between individual and organizational mindfulness is examined. Some authors consider these concepts to be interconnected, but the exact nature of this connection is still unclear. Research shows that organizational mindfulness implies mindfulness at the individual level.

The data of other researchers also show similar tendencies: intentions of the individual to continue the chosen activity having encountered obstacles (Hoyle, 2006), achievement motivation, perseverance in attainment of set goals and coping with challenges (Judge, Ilies, 2002; Shafi et al., 2020; Tse et al., 2018; Wang, 2020) are linked to creativity. The results of Huang \& Luthans (2015); Song, Yu, Zhang, \& Jiang (2015) research also show that the person's persistence seeking the established goals and not giving in to obstacles, targeting at high achievements, generation of new ideas can be of high importance in the process of creative thinking. Therefore, it can be assumed that the higher level of person's resistance to failures and obstacles, positive evaluation of own achievements without experiencing any guilt positively influence manifestation of creativity, ambition to seek high goals, ability to make plans and expand limits of own possibilities.

The authors (Griffiths, Costi, 2020) do not deny and acknowledge that creativity is related to social competence, because creativity is more than just mobilizing people when, on the contrary, being together with other personal clear creative, idea-based goals. Creativity should be addressed to other business processes where it is important not only to develop financial measurement products but also to delve into human resources in a modern organization. This allows us to state that various necessary aspects of social communication are the acceptance of another's opinion, the ability to express oneself clearly, the ability to ask for or give help. Glăveanu (2014) notes that creative action is characterized by processes of human interaction and communication.

A big number of studies confirm relationships of the person's ability to act creatively, to establish successful relations and maintain them. It can be assumed that a higher value of social activity is connected to formation of person's more favourable attitude to himself/herself and conducted activities including creative activities. Our research and the ones conducted by other researchers showed a positive correlation between the ability to maintain constructive and good relations with others and creativity (Sung, Choi, 2009). This confirms the statement that people, who possess a higher level of maintaining constructive relations and social openness, focused on people, able to establish contacts easier and to engage in joint activities and spend more time communicating with others, are able to create, generate new ideas and to accept challenges and innovations. The results of our research also confirmed that personal emotional openness, ability to maintain constructive relations with others is a significant determinant for creativity. The fact that creativity is not a vacuum process decoupled from social competence is also acknowledged by Glăveanu (2014) and Elisondo (2016), noting that creativity is a social action and is not performed in solitude. This is because the activities of individuals depend on the opinions and acceptance of other people. Even an individual creative process is not in itself separate, more and more a person does it in a socially constructed context, which is determined by language, knowledge, expectations.

Importantly, the scientific literature places significant emphasis on social expectations, as individuals 'perceptions of the creative expectations that are raised in organizations also enhance the creativity of the latter (Farmer, Tierney, \& Kung-McIntyre, 2003). Communication is one of the essential functions in business, important in creating, transmitting and interpreting ideas, this suggests that certain aspects of social competence - ability to 


\section{ENTREPRENEURSHIP AND SUSTAINABILITY ISSUES}

ISSN 2345-0282 (online) http://jssidoi.org/jesi/

2021 Volume 8 Number 3 (March)

http://doi.org/10.9770/jesi.2021.8.3(20)

accept criticism, resilience, to express one's position and feelings - are important in business communication. Businesses also focus on innovative creativity and the development of a creative work environment to create unique business results. To respond to this goal, according to Sipahi (2018), the ability to compete, to take initiative decisions is important. Researchers (Farmer, Tierney, \& Kung-McIntyre, 2003; Prabhu et al., 2008) have focused on personality factors: self-knowledge, self-efficacy perceptions that affect employee creativity. Other researchers note that self-regulatory abilities and even a person's positive mood can affect a person's creativity (Roskes, De Dreu, \& Nijstad, 2012). Authors confirm that the stronger the individual's ability of expressing feelings, the weaker his/her emotional inhibition, the less constrained the person is in communication situations, the braver his/her expression of opinion is and the less afraid s/he is to make new acquaintances and express the feelings in appropriate ways, the more new ideas such a person generates and the easier he is able to express them. Other researchers (Broekhoven, Cropley, \& Seegers, 2020; Camargo, Çelik, \& Storme, 2020; Feist, 1998) have identified the existing expression of divergent creative thinking. a statistically significant relationship between the expression of emotionality and creativity. Research by Sung, Choi (2009) has revealed similar trends - individuals with stronger emotional sensitivity tend to generate new ideas, as well as curiosity, interest in the environment around them, the ability to think creatively, act in unconventional ways and accept boldly. The results of research by Pacevičius (2005), Rantanen et al. (2007) show that more closed and emotionally engaged individuals, more often experiencing negative emotions, unable to express them in appropriate ways, as well as more often experiencing tension in communication situations, who likely to limit the opportunities for expression of creativity. Other researchers has also revealed similar trends, with a person's persistence in pursuing the chosen activity despite difficulties and obstacles (Hoyle, 2006; Rantanen et al., 2007) and a stronger commitment to achieving goals are associated with the manifestation of creativity, as it is likely that a person capable of accepting negative assessments and disagreements from others and respond to failures, and persevere in achieving the set goals, has a higher level of creativity, is more flexible and original in performing activities.

\section{Research objective and methodology}

The research participants. The research sample included 176 students of social profile from Lithuanian higher education schools: $108(61.4 \%)$ female and $68(38.6 \%)$ male students. There were $54(30.7 \%)$ first year, 48 $(27.3 \%)$ second year, $44(25 \%)$ third year and $30(17 \%)$ fourth year students. The average age of respondents was 20.8 years. Attempts were made to include students of social profile from various Lithuanian schools of higher education into the quantitative research. The research sample was convenient. Anonymity was ensured during the research and the ethical principle of free choice to participate in the survey was followed. The received results were processes and presented in a generalised manner, confidentiality of data was guaranteed and the participants were informed about the details of research completion.

The research methods. Analytical descriptive method was used to analyse peculiarities of social competence and creativity, possibilities for creativity manifestation based on the level of social competence. The quantitative research. The strategy of quantitative research was applied to investigate expression of creativity, social competence among students from Lithuanian higher education institutions and their correlations and to foresee social competence-based prognostic possibilities. The students' social competence was assessed using the questionnaire of Ullriche, de Muynck (1994) (cf. Lekavičiene, 2001). The questionnaire consists of 45 statements with six variants or responses: from 0 ("This is not the case at all, completely untrue") to 5 ("Completely true"). The indicators are calculated according to seven scales: 1) general self-confidence (provides information on the respondent's self-confidence, perception of own relevance, determination); 2) resistance to failures and criticism (allows evaluating the participant's ability to accept negative evaluation and disapproval of surrounding people); 3 ) ability of expressing feelings (evaluates the participant's ability to show own positive and negative feelings, to discuss them with other people); 4) ability of asking for a favour (helps to evaluate the participant's ability to contact with familiar and unfamiliar people); 5) unyielding (allows evaluating the participant's behaviour regarding the requirements from other people); 6) ability of demanding (shows the participant's ability to make complaints 


\section{ENTREPRENEURSHIP AND SUSTAINABILITY ISSUES}

ISSN 2345-0282 (online) http://jssidoi.org/jesi/

2021 Volume 8 Number 3 (March)

http://doi.org/10.9770/jesi.2021.8.3(20)

and formulate requirements); 7) feeling not guilty (allows evaluating a sense of guilt, which can arise after not satisfying requests or requirements of other peoples). Reliability of questionnaire. The results of statistical data analysis show that the internal consistency of all the scales of the Lithuanian versions of Social Competence Questionnaire is good; according to separate factors, the Cronbach alpha varies from 0.61 to 0.79 (Lekavičienè, 2001). The students' perceived creativity was investigated applying The Questionnaire of Personality Creativity (Petrulis, 1988). From the author's perspective, creativity is a particularly complex, multi-sided dimension, which manifests itself at the levels: 1) behaviour and activity, 2) thinking (e.g., generation of ideas, etc.) and 3) personality. The questionnaire form consists of 64 statements, where the respondents are requested to answer "Yes" or "No". The results are analysed according to the subscales of intuition, phantasy, inclination to creativity, inclination to innovation, flexibility, originality, criticism, intensity and childishness. The results of statistical data analysis show that internal consistency of all the scales of Questionnaire of Personality Creativity is good; according to the separate scales the Cronbach alpha varies from 0.75 to 0.85 . The analysis of internal consistency of Questionnaire of Personality Creativity (Cronbach alpha) revealed its relatively high level: intuition -0.85 . phantasy -0.82 . inclination to creativity -0.75 . inclination to innovation -0.83 . flexibility -0.82 . originality 0.77. criticism -0.81 . inversion -0.79 and childishness -0.81 . Statistical method of research. To process the data collected during the research, the Pearson correlation coefficient aiming to evaluate correlations between the participants' creativity and social competence indicators as well as multiple linear regression analysis were applied. The obtained results are regarded to be statistically significant, when they are in line with the significance level $p$. The statistical analysis of data was carried out applying SPSS 17 (Statistic Package for Social Sciences).

\section{The research results and their analysis}

Peculiarities of social competence. The received values of social competence were calculated after processing the data of Social Competence Questionnaire (Ullriche, de Muynck, 1994. cf. Lekavičienè, 2001). The average values of social competence in the general sample are presented in Picture 1.

As it can be seen from the research results, general self-confidence $(\mathrm{V}=28.6)$ and resistance to failures and criticism (V=25.39) were strongest expressed among students. The latter results refer to successful psychosocial functioning of students in social contexts when in the communication situations positive interpersonal relations are formed being self-confident and reliant on own possibilities, when making decisions own significance is perceived and reaction to criticism and failures is adequate. The lowest average values were established in the three subscales: ability of demanding $(\mathrm{V}=13.6)$, feeling not guilty $(\mathrm{V}=14.2)$ and ability of asking for a favour $(\mathrm{V}=14.56)$. This reveals weaker developed social-cognitive abilities of making complains or formulating requirements or expressing wishes to the surrounding people, making decisions and defending own rights. It also refers to weaker expression of dependence on others, a sense of guilty failing to satisfy requests of other people and a lack of adequate attitude towards a possibility of satisfying requirements of surrounding people. 


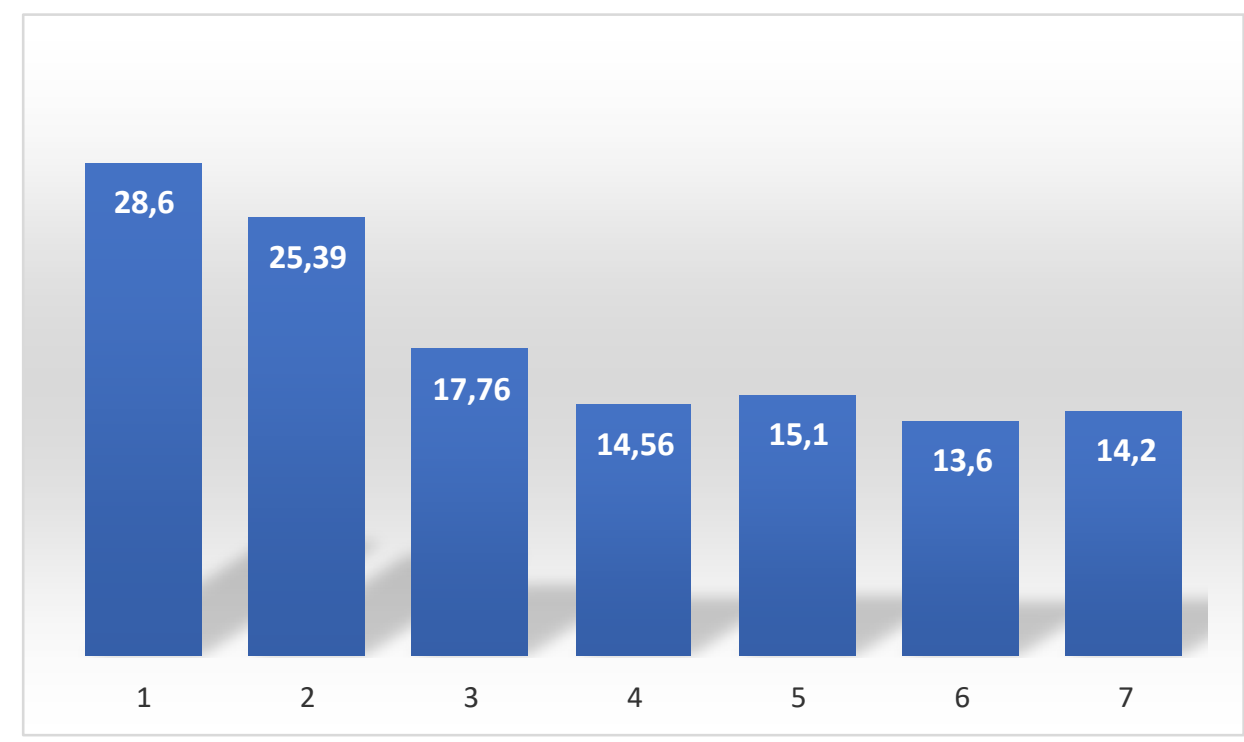

Figure 1. The average values of social competence of students $(n=176)$

Remark:

1 - General self-confidence

2 - Resistance to failures and criticism

3 - Ability of expressing feelings
4 - Ability of asking for a favour

5 - Unyielding

6 - Ability of demanding

7 - Feeling not guilty

The generalised research results allow stating that the students, who participated in the research, are selfconfident and are distinguished by high level of ability to resist failures and research, whereas ability of asking for a favour and demanding as well as feeling of not guilty are expressed in a weaker way.

Peculiarities of perceived creativity. Expressivity of perceived creativity components among students was calculated applying The Questionnaire of Personality Creativity (Петрулис, 1988). The generalised average values of creativity among students are presented in Figure 2.

The results of conducted analysis of The Questionnaire of Personality Creativity showed that the highest average values were established in the subscales of inclination to innovation $(\mathrm{V}=5.38)$ and childishness $(\mathrm{V}=5.63)$. Such results disclose the inclination of the person to innovations, generation of new ideas and his/her wish to work with them as well as inclination to experiments, self-testing, stronger expressed sincerity, naivety, emotionality, impulsivity, vivid imagination, openness and sensitivity. On the other hand, the research showed that students attributed relatively high average values to originality $(\mathrm{V}=4.82)$ and pursuit of creativity $(\mathrm{V}=3.79)$. Moreover, the lowest values identified in the subscales of intuition $(\mathrm{V}=1.81)$ and inversion $(\mathrm{V}=2.28)$ allow stating that the participants in the research possessed a weaker expressed ability of changing direction or system of ideas and tended to perform assignments in the usual established order. The research results also show that in the group of students, the environment perception and conclusion making are linked to experience, long considerations and searching for justifying arguments rather than based on inner intuition. The total average of values of all the scales in The Questionnaire of Personality Creativity equals 31.93. 


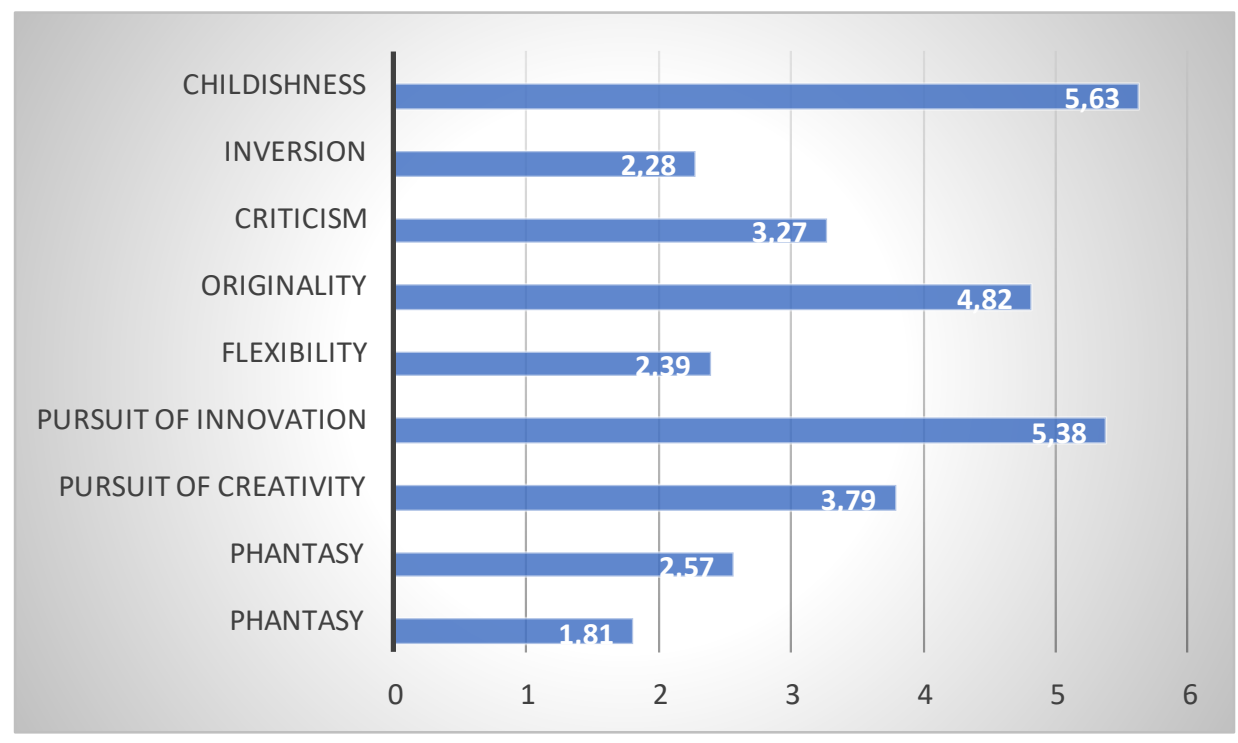

Figure 2. Average values of perceived creativity of students $(n=176)$

After the generalisation of results, high average values of subscales of pursuit of innovation and creativity as well as childishness and originality among students in the research were observed. It means that the respondents consider themselves to be original individuals, who pursue innovation and creativity, are not afraid to experiment and have vivid imagination. However, the research also revealed that the students also acknowledge having weaker expressed intuition and are distinguished by a lower indicator of inversion expressivity.

Correlations of perceived creativity and social competence of social profile students. Seeking to identify if students' social competence and perceived creativity are interrelated, the statistical data analysis was conducted and Pearson correlation coefficients were calculated. The results of correlation analysis are presented in Table 1. The calculations of Pearson correlation coefficients showed correlation of total creativity indicator with all the components of social competence with exception of the subscales of ability of asking for a favour $(\mathrm{p}=0.451)$ and ability of demanding $(\mathrm{p}=0.62)$. The study of relations between variables of social competence and perceived creativity disclosed rather strong positive correlations between the total creativity indicator and general selfconfidence $(\mathrm{p}=0.001)$ and unyielding $(\mathrm{p}=0.001)$. A weak correlation was identified with the indicator of resistance to failures and criticism $(\mathrm{p}=0.011)$, and a weak negative correlation was established between the total creativity indicator and the subscale of feeling not guilty $(\mathrm{p}=0.019)$. This allows stating that slightly higher total creativity indicator is characteristic of students, who are self-confident, perceive own significance, are able to say "No", not to give in to personally disadvantageous situations and who posses ability to accept negative evaluations and disapproval as well as are more resistant to failures and criticism, compared to the ones, who experience a sense of helplessness and fear of not being able to provide help to others or are vulnerable and unable to react to criticism and failures in adequate ways. Rather relevant results are observed after a sufficiently significant correlation was identified between the total creativity indicator and ability of expressing feelings $(\mathrm{p}=0.001)$. Thus, the more expressed the ability to establish constructive relations with others and to discuss their experiences with them and benevolence in the process of communication are, the higher creativity of an individual is observed.

The results of correlation analysis disclosed statistically significant correlations between variables of social competence and certain indicators of perceived creativity. The correlation analysis of separate subscales of social competence and creativity in the group of students showed weak but statistically significant positive correlations between general self-confidence and such subscales of creativity as intuition $(\mathrm{p}=0.002)$, phantasy $(\mathrm{p}=0.008)$, pursuit of innovation $(\mathrm{p}=0.002)$, originality $(\mathrm{p}=0.002)$ and criticism $(\mathrm{p}=0.002)$. Thus, it can be noted that self- 


\section{ENTREPRENEURSHIP AND SUSTAINABILITY ISSUES}

ISSN 2345-0282 (online) http://jssidoi.org/jesi/

2021 Volume 8 Number 3 (March)

http://doi.org/10.9770/jesi.2021.8.3(20)

confident research participants, who perceive their significance and relevance and pursue their set goals in a determined way see themselves as original individuals, who pursue innovation, possess vivid imagination and are more critical personalities.

After the calculation of Pearson correlation coefficients, in the group of research participants rather strong statistically significant positive correlations were found between unyielding and originality $(\mathrm{p}=0.002)$, criticism $(\mathrm{p}=0.003)$, phantasy $(\mathrm{p}=0.003)$ and flexibility $(\mathrm{p}=0.001)$. Slightly weaker but still statistically significant correlations were identified between pursuit of innovation $(\mathrm{p}=0.006)$ and inversion $(\mathrm{p}=0.007)$. Thus, the participants with higher level of ability to respond to requirements from other people in adequate ways and not to give in to personally disadvantageous situations, with ability to put forward their wishes and to protect own rights, to say "No" and able not to feel tension in communication situation are distinguished by stronger expressed phantasy, inversion, originality, flexibility as well as criticism while performing assignments and pursuit of innovation.

The correlation analysis of subscales of perceived creativity and social competence revealed positive correlations between the participants' ability of expressing feelings and the following subscales of creativity: flexibility $(\mathrm{p}=0.001)$, childishness $(\mathrm{p}=0.002)$, originality $(\mathrm{p}=0.003)$, criticism $(\mathrm{p}=0.004)$, pursuit of innovation $(\mathrm{p}=0.002)$ and creativity $(\mathrm{p}=0.004)$. The aforesaid allows pointing out that the students, who demonstrate better expressed confidence in other individuals while establishing contact with them, benevolence while communicating with others and discussing the feelings they are going through, give higher evaluation to their flexibility, originality, childlessness and criticism as well as have stronger expressed pursuit of innovation and creativity.

The calculated Pearson correlation coefficients disclosed negative correlations between the subscales of feeling not guilty and phantasy $(\mathrm{p}=0.002)$ as well as childishness $(\mathrm{p}=0.001)$; a relatively weak but positive correlation was identified with the subscale of criticism $(\mathrm{p}=0.017$ ). This allows stating that social profile students, who possess weaker responsibility for solving problems of other people and less frequently experience a sense of guilt not being able to help others, are distinguished by stronger expressed phantasy and childishness, whereas the participants with stronger expressed adequate attitude to a possibility of satisfying requirements of other people leads to a higher level of criticism. Important results are observed after establishing strong positive correlations between the indicator of resistance to failures and criticism and intuition $(\mathrm{p}=0.001)$, creativity $(\mathrm{p}=0.001)$ and pursuit of innovation $(\mathrm{p}=0.001)$ and weak positive significant correlations with flexibility $(\mathrm{p}=0.014)$ and originality $(\mathrm{p}=0.017)$. Following the results of research, it can be noted that the participants' ability to adequately react to negative evaluations and disapproval of surrounding people and to accept them precondition stronger expressed intuition, flexibility, originality, pursuit of innovation and creativity. On the opposite, the stronger expressed fear of getting at the forefront, an experienced sense of helplessness as well as vulnerability and lack of ability to react to criticism and failures adequately are linked to weaker expression of flexibility, originality, intuition as well as pursuit of innovation and creativity among the social-profile students in the research. A weak but significantly positive correlation found between resistance to failures and criticism and criticism $(\mathrm{p}=0.008)$ shows that stronger expressed criticism is typical of the research participants who are able to react to failures and criticism in adequate ways and to accept negative evaluations of and disapproval of surrounding people and are not afraid to get at the forefront. The correlation analysis of perceived creativity and social competence revealed relatively weak but significantly positive correlations between ability of asking for a favour and pursuit of creativity $(\mathrm{p}=0.009)$, flexibility $(\mathrm{p}=0.004)$ and originality $(\mathrm{p}=0.009)$. Thus, it can be stated that the respondents, who are distinguished by a stronger expressed ability of asking for a favour, absence of fear of being rejected or being a burden to the surrounding people, evaluate higher their own originality and flexibility as well as pursuit of creativity. The calculations of Pearson correlation coefficients disclosed moderate positive correlations between the subscales of ability of demanding and criticism $(\mathrm{p}=0.001)$ and pursuit of innovation $(\mathrm{p}=0.009)$. Also, only negative correlation with childishness $(\mathrm{p}=0.003)$ shows that a stronger expressed ability of students to make complaints and formulate requirements, to present own wishes and to defend them as well as stronger manifested 


\section{ENTREPRENEURSHIP AND SUSTAINABILITY ISSUES}

ISSN 2345-0282 (online) http://jssidoi.org/jesi/

2021 Volume 8 Number 3 (March)

http://doi.org/10.9770/jesi.2021.8.3(20)

aggressive behaviour and disregard of others around result in stronger expressed criticism and pursuit of innovation. Meanwhile, a stronger expressed feature of childishness is typical of weaker expressed ability of respondents to defend their rights using appropriate ways.

Table 1. The results of correlation analysis of features of students' personality and creativity $(\mathrm{n}=176)$

\begin{tabular}{|c|c|c|c|c|c|c|c|}
\hline & $\begin{array}{l}\text { General self- } \\
\text { confidence }\end{array}$ & $\begin{array}{l}\text { Resistance to } \\
\text { failures and } \\
\text { criticism }\end{array}$ & $\begin{array}{l}\text { Ability of } \\
\text { expressing } \\
\text { feelings }\end{array}$ & $\begin{array}{l}\text { Ability of } \\
\text { asking for a } \\
\text { favour }\end{array}$ & Unyielding & $\begin{array}{l}\text { Ability of } \\
\text { demandin } \\
\mathrm{g}\end{array}$ & $\begin{array}{l}\text { Not } \\
\text { feeling } \\
\text { guilty }\end{array}$ \\
\hline Intuition & $\begin{array}{l}0.192 * * \\
0.002\end{array}$ & $\begin{array}{l}0.349 * * \\
0.001\end{array}$ & $\begin{array}{l}0.092 \\
0.12\end{array}$ & $\begin{array}{l}0.107 \\
0.078\end{array}$ & $\begin{array}{l}0.088 \\
0.141\end{array}$ & $\begin{array}{l}0.073 \\
0.21\end{array}$ & $\begin{array}{l}0.064 \\
0.471\end{array}$ \\
\hline Phantasy & $\begin{array}{l}0.161 * * \\
0.008\end{array}$ & $\begin{array}{l}0.046 \\
0.483 \\
\end{array}$ & $\begin{array}{l}0.057 \\
0.492 \\
\end{array}$ & $\begin{array}{l}0.032 \\
0.71 \\
\end{array}$ & $\begin{array}{l}\mathbf{0 . 2 0 4} * * \\
\mathbf{0 . 0 0 3} \\
\end{array}$ & $\begin{array}{l}0.038 \\
0.48 \\
\end{array}$ & $\begin{array}{l}\mathbf{- 0 . 1 8 2} * * * \\
\mathbf{0 . 0 0 2}\end{array}$ \\
\hline $\begin{array}{l}\text { Pursuit of } \\
\text { creativity }\end{array}$ & $\begin{array}{l}0.044 \\
0.464 \\
\end{array}$ & $\begin{array}{l}0.325 * * \\
0.001\end{array}$ & $\begin{array}{l}\text { 0.176* } \\
0.004\end{array}$ & $\begin{array}{l}0.157^{*} \\
0.009 \\
\end{array}$ & $\begin{array}{l}0.1 \\
0.094 \\
\end{array}$ & $\begin{array}{l}0.079 \\
0.397 \\
\end{array}$ & $\begin{array}{l}0.092 \\
0.117 \\
\end{array}$ \\
\hline $\begin{array}{l}\text { Pursuit of } \\
\text { innovation }\end{array}$ & $\begin{array}{l}\text { 0.208*** } \\
0.002\end{array}$ & $\begin{array}{l}0.297 * * \\
0.001\end{array}$ & $\begin{array}{l}0.263 * * \\
0.002\end{array}$ & $\begin{array}{l}0.089 \\
0.18\end{array}$ & $\begin{array}{l}\text { 0.154** } \\
0.006\end{array}$ & $\begin{array}{l}0.197 * * \\
0.009\end{array}$ & $\begin{array}{l}0.073 \\
0.218 \\
\end{array}$ \\
\hline Flexibility & $\begin{array}{l}0.066 \\
0.271 \\
\end{array}$ & $\begin{array}{l}0.148 * \\
0.014\end{array}$ & $\begin{array}{l}0.291 * * \\
0.001\end{array}$ & $\begin{array}{l}\text { 0.169* } \\
0.004\end{array}$ & $\begin{array}{l}0.285^{* *} \\
\mathbf{0 . 0 0 1} \\
\end{array}$ & $\begin{array}{l}0.054 \\
0.396 \\
\end{array}$ & $\begin{array}{l}-0.078 \\
0.21 \\
\end{array}$ \\
\hline Originality & $\begin{array}{l}\mathbf{0 . 2 1 2} * * * \\
\mathbf{0 . 0 0 2}\end{array}$ & $\begin{array}{l}\text { 0.159* } \\
0.017\end{array}$ & $\begin{array}{l}0.195 * * \\
0.003\end{array}$ & $\begin{array}{l}\text { 0.153* } \\
0.009\end{array}$ & $\begin{array}{l}\mathbf{0 . 2 7 2} * * \\
\mathbf{0 . 0 0 2}\end{array}$ & $\begin{array}{l}0.039 \\
0.51 \\
\end{array}$ & $\begin{array}{l}-0.085 \\
0.152 \\
\end{array}$ \\
\hline Criticism & $\begin{array}{l}0.187 * * \\
0.002\end{array}$ & $\begin{array}{l}\text { 0.163* } \\
0.008\end{array}$ & $\begin{array}{l}\text { 0.173* } \\
0.004\end{array}$ & $\begin{array}{l}0.036 \\
0.68 \\
\end{array}$ & $\begin{array}{l}0.246 * * \\
0.003\end{array}$ & $\begin{array}{l}\mathbf{0 . 2 5 3} * * \\
\mathbf{0 . 0 0 1}\end{array}$ & $\begin{array}{l}\text { 0.148* } \\
0.017\end{array}$ \\
\hline Inversion & $\begin{array}{l}-0.034 \\
0.56 \\
\end{array}$ & $\begin{array}{l}0.084 \\
0.401 \\
\end{array}$ & $\begin{array}{l}0.041 \\
0.53\end{array}$ & $\begin{array}{l}0.066 \\
0.41\end{array}$ & $\begin{array}{l}0.16^{*} \\
0.007\end{array}$ & $\begin{array}{l}0.021 \\
0.742 \\
\end{array}$ & $\begin{array}{l}0.048 \\
0.59 \\
\end{array}$ \\
\hline Childishness & $\begin{array}{l}-0.018 \\
0.804 \\
\end{array}$ & $\begin{array}{l}0.098 \\
0.307 \\
\end{array}$ & $\begin{array}{l}\mathbf{0 . 2 8 8} * * \\
\mathbf{0 . 0 0 2} \\
\end{array}$ & $\begin{array}{l}-0.075 \\
0.32 \\
\end{array}$ & $\begin{array}{l}-0.102 \\
0.089 \\
\end{array}$ & $\begin{array}{l}-\mathbf{0 . 2 1 8} * * \\
\mathbf{0 . 0 0 3}\end{array}$ & $\begin{array}{l}\mathbf{- 0 . 2 1 6} * * * \\
0.001\end{array}$ \\
\hline Total average & $\begin{array}{l}0.35 * * \\
0.001 \\
\end{array}$ & $\begin{array}{l}\mathbf{0 . 1 8 8} * * \\
\mathbf{0 . 0 1 1}\end{array}$ & $\begin{array}{l}0.32 * * \\
0.001 \\
\end{array}$ & $\begin{array}{l}0.046 \\
0.451 \\
\end{array}$ & $\begin{array}{l}0.371 * * \\
0.001\end{array}$ & $\begin{array}{l}0.035 \\
0.62 \\
\end{array}$ & $\begin{array}{l}-0.156 * \\
0.019 \\
\end{array}$ \\
\hline
\end{tabular}

$* \mathrm{p}<0.01 ; * * \mathrm{p}<0.001)$

The generalized results of correlation analysis allow stating that self-confident students, who are able to accept negative evaluations and disapproval of surrounding people and are resistant to failures and criticism, demonstrate a higher total indicator of creative personality. It was established that general self-confidence and perception of own significance result in stronger expression of intuition, phantasy, criticism, originality and pursuit of innovation. The results also showed that the participants with a stronger expressed ability to express feelings in appropriate ways, demonstrate stronger expression of creativity and pursuit of innovation as well as flexibility, originality, childishness and criticism. It was also noticed that being able to appropriately accept negative evaluations and disapproval of surrounding people and to adequately react to failures and criticism, the students, who are not afraid of getting at the forefront, demonstrate stronger expressed criticism, intuition, flexibility and originality, pursuit of innovation and creativity. The students, who are able to ask for a favour and are not afraid to be rejected tend to evaluate their originality, flexibility and pursuit of creativity higher. Thus, the conducted correlation analysis allowed identifying statistically significant correlations between the students' social competence and perceived creativity. However, the correlations among variables were rather weak.

Social competence-based prognostic possibilities of creativity expression among students of social profile. The correlation analysis revealed statistically significant correlations between the evaluation of students' perceived creativity and social competence. However, it should be acknowledged that correlations express more or less probable statistical tendencies and show an approximate compatibility of two variables and tend to be more stochastic (Vaitkevičius, Saudargienè, 2006). For this reason, the regression analysis was conducted, which allowed foreseeing prognostic possibilities of some (dependent) variables on the basis of other (independent) variables from the regression equation. The regressive analysis of variables is presented in Table 2.

The relationship of present and estimated expression of creativity according to separate indicators ranges from 0.24 to 0.328 among participants of the research. The values of the latter determination coefficients show a rather 


\section{ENTREPRENEURSHIP AND SUSTAINABILITY ISSUES}

ISSN 2345-0282 (online) http://jssidoi.org/jesi/

2021 Volume 8 Number 3 (March)

http://doi.org/10.9770/jesi.2021.8.3(20)

weak power of social competence (independent variable) in forecasting creativity (dependent variable), and this allows assuming that on the basis of the components of social competence the forecasted expression of students' perceived creativity may range only from $3.3 \%$ to $8.9 \%$. The results of linear regression analysis in the group of students disclosed that the regression $\mathrm{R}$ of the subscales of inversion $(\mathrm{p}=0.061)$ and intuition $(\mathrm{p}=0.069)$ does not significantly exceed the zero (see: Table 2 ).

Table 2. The correlation coefficient $\mathrm{R}$ and determination coefficient $\mathrm{R}$ of dependent variables (perceived creativity) and independent variables (social competence) in the group of social profile students-participants in the research

\begin{tabular}{|l|c|c|c|c|c|c|c|c|}
\hline Name of scale & $\mathrm{R}$ & $\mathrm{R}$ & Corrected R & $\begin{array}{c}\text { Type III } \\
\text { sums of } \\
\text { squares }\end{array}$ & $\begin{array}{c}\text { Degree } \\
\text { of } \\
\text { freedom } \\
\text { (df) }\end{array}$ & $\begin{array}{c}\text { Mean of } \\
\text { squares }\end{array}$ & $\mathrm{F}$ & $\mathrm{p}$ \\
\hline Intuition & 0.214 & 0.046 & 0.022 & 179.501 & 10 & 25.643 & 1.913 & 0.069 \\
\hline Phantasy of & 0.273 & 0.075 & 0.051 & 130.476 & 10 & 18.639 & 3.206 & $\mathbf{0 . 0 0 3}$ \\
\hline $\begin{array}{l}\text { Pursuit } \\
\text { creativity }\end{array}$ & 0.24 & 0.058 & 0.033 & 325.0 & 10 & 46.429 & 2.289 & $\mathbf{0 . 0 2 8}$ \\
\hline $\begin{array}{l}\text { Pursuit } \\
\text { innovation }\end{array}$ & 0.27 & 0.073 & 0.048 & 184.073 & 10 & 26.296 & 2.923 & $\mathbf{0 . 0 0 6}$ \\
\hline Flexibility & 0.256 & 0.065 & 0.04 & 253.085 & 10 & 36.155 & 2.612 & $\mathbf{0 . 0 1 3}$ \\
\hline Originality & 0.273 & 0.075 & 0.05 & 205.958 & 10 & 29.432 & 3.004 & $\mathbf{0 . 0 0 5}$ \\
\hline Criticism & 0.243 & 0.061 & 0.035 & 361.212 & 10 & 51.602 & 2.566 & $\mathbf{0 . 0 1 4}$ \\
\hline Inversion & 0.219 & 0.048 & 0.024 & 109.815 & 10 & 15.688 & 1.994 & 0.061 \\
\hline Childishness & 0.328 & 0.106 & 0.089 & 354.569 & 10 & 50.653 & 4.726 & $\mathbf{0 . 0 0 1}$ \\
\hline Total indicator & 0.253 & 0.064 & 0.04 & 126.071 & 10 & 18.01 & 2.716 & $\mathbf{0 . 0 1}$ \\
\hline
\end{tabular}

The results of conducted linear regression analysis showed that the variables of general self-confidence $(\mathrm{p}=0.001)$, ability of expressing feelings $(\mathrm{p}=0.001)$, unyielding $(\mathrm{p}=0.007)$ and ability of demanding $(\mathrm{p}=0.004)$ are significant prognostic indicators of inclination to innovation. It was also established that the expression of inclination to innovation is significantly foreseen by the variable of resistance to failures and criticism $(\mathrm{p}=0.012$ ) (see: Table 3). Moreover, the variable general self-confidence is significant for forecasting expression of intuition ( $\mathrm{p}=0.007)$, (see: Table 3), originality $(\mathrm{p}=0.002)$ and criticism $(\mathrm{p}=0.017)$ (see: Table 4). It was also revealed that pursuit of creativity $(\mathrm{p}=0.001)$ (see: Table 3 ) and the person's originality $(\mathrm{p}=0.001)$ (see: Table 4$)$ significantly forecast the variable resistance to failures and criticism, whereas the variable unyielding $(\mathrm{p}=0.008)$ and ability of demanding $(\mathrm{p}=0.006)$ are significant prognostic indicators of criticism (see: Table 4). The results of linear regression analysis disclose that the expression of participants' flexibility can be significantly foreseen by the following three variables of social competence: resistance to failures and criticism $(\mathrm{p}=0.003)$, ability of asking for a favour $(\mathrm{p}=0.001)$ and unyielding $(\mathrm{p}=0.002)$, whereas the expression of phantasy is predetermined by the variables of general self-confidence $(\mathrm{p}=0.001)$, resistance to failures and criticism $(\mathrm{p}=0.001)$ and unyielding $(\mathrm{p}=0.025)($ see: Table 3). On the other hand, the research results showed that the variable feeling not guilty is a significant prognostic indicator of phantasy $(\mathrm{p}=0.016)$ and pursuit of creativity $(\mathrm{p}=0.001)$ (see: Table 3$)$, whereas the variable ability of expressing feelings is a significant indicator of intuition $(\mathrm{p}=0.001)$ (see: Table 3$)$, childishness $(\mathrm{p}=0.026)$ and originality $(\mathrm{p}=0.011)$ (see: Table 4$)$. The results of regression analysis show that general self-confidence $(\mathrm{p}=0.027)$, resistance to failures and criticism $(\mathrm{p}=0.003)$ and unyielding $(\mathrm{p}=0.001)$ are significant prognostic indicators of total creativity of research participants. 


\section{ENTREPRENEURSHIP AND SUSTAINABILITY ISSUES}

ISSN 2345-0282 (online) http://jssidoi.org/jesi/

2021 Volume 8 Number 3 (March)

http://doi.org/10.9770/jesi.2021.8.3(20)

Table 3. The regression equation coefficients (B), normalized coefficients $(\beta)$ and significance level (p) of regression equation of values of students' perceived creativity and social competence $(\mathrm{p})$

\begin{tabular}{|c|c|c|c|c|c|c|c|c|c|c|c|c|c|c|c|}
\hline & \multicolumn{3}{|c|}{ Intuition } & \multicolumn{3}{|c|}{ Phantasy } & \multicolumn{3}{|c|}{ Pursuit of creativity } & \multicolumn{3}{|c|}{ Pursuit of innovation } & \multicolumn{3}{|c|}{ Flexibility } \\
\hline & $B$ & $\beta$ & $p$ & $B$ & $\beta$ & $p$ & $B$ & $\beta$ & $p$ & $B$ & $\beta$ & $p$ & $B$ & $\beta$ & $p$ \\
\hline 1 & 0.486 & 0.181 & 0.007 & 1.16 & 0.301 & 0.001 & 0.372 & 0.112 & 0.057 & 0.795 & 0.257 & 0.001 & 0.441 & 0.112 & 0.064 \\
\hline 2 & 0.203 & 0.11 & 0.053 & 0.62 & 0.271 & 0.001 & 0.785 & 0.264 & 0.001 & 0.447 & 0.151 & 0.012 & 0.51 & 0.218 & 0.003 \\
\hline 3 & 0.482 & 0.224 & 0.001 & 0.119 & 0.096 & 0.107 & 0.381 & 0.115 & 0.057 & 0.71 & 0.209 & 0.001 & 0.182 & 0.076 & 0.228 \\
\hline 4 & 0.243 & 0.071 & 0.19 & 0.247 & 0.128 & 0.061 & 0.198 & 0.091 & 0.07 & 0.219 & 0.082 & 0.139 & 0.42 & 0.266 & 0.001 \\
\hline 5 & 0.201 & 0.079 & 0.103 & 0.327 & 0.148 & 0.025 & 0.213 & 0.115 & 0.058 & 0.497 & 0.168 & 0.007 & 0.47 & 0.217 & 0.002 \\
\hline 6 & 0.212 & 0.096 & 0.121 & 0.123 & 0.07 & 0.331 & 0.126 & 0.049 & 0.318 & 0.465 & 0.183 & 0.004 & 0.206 & 0.081 & 0.194 \\
\hline 7 & 0.211 & 0.104 & 0.061 & $\begin{array}{c}- \\
0.461\end{array}$ & $\begin{array}{c}- \\
0.174\end{array}$ & 0.016 & $\begin{array}{c}- \\
1.106\end{array}$ & $\begin{array}{c}- \\
0.279\end{array}$ & 0.001 & 0.131 & 0.083 & 0.169 & 0.206 & 0.079 & 0.081 \\
\hline
\end{tabular}

Table 4. The regression equation coefficients (B), normalized coefficients ( $\beta$ ) and significance level (p) of regression equation of values of students' perceived creativity and social competence $(\mathrm{p})$

\begin{tabular}{|c|c|c|c|c|c|c|c|c|c|c|c|c|c|c|c|}
\hline & \multicolumn{3}{|c|}{ Originality } & \multicolumn{3}{|c|}{ Criticism } & \multicolumn{3}{|c|}{ Inversion } & \multicolumn{3}{|c|}{ Childishness } & \multicolumn{3}{|c|}{ Total indicator } \\
\hline & $B$ & $\beta$ & $p$ & $B$ & $\beta$ & $p$ & $B$ & $\beta$ & $p$ & $B$ & $\beta$ & $P$ & $B$ & $\beta$ & $p$ \\
\hline 1 & 0.468 & 0.269 & 0.002 & 0.414 & 0.198 & 0.017 & 0.212 & 0.93 & 0.122 & 0.327 & 0.124 & 0.058 & 0.336 & 0.141 & $\mathbf{0 . 0 2 7}$ \\
\hline 2 & 0.738 & 0.283 & 0.001 & 0.142 & 0.084 & 0.246 & 0.201 & 0.113 & 0.062 & 0.167 & 0.122 & 0.061 & 0.412 & 0.185 & 0.003 \\
\hline 3 & 0.459 & 0.193 & 0.011 & 0.135 & 0.061 & 0.31 & 0.181 & 0.118 & 0.056 & 0.335 & 0.171 & 0.026 & 0.181 & 0.076 & 0.129 \\
\hline 4 & 0.146 & 0.087 & 0.19 & 0.147 & 0.074 & 0.197 & 0.193 & 0.096 & 0.092 & 0.169 & 0.102 & 0.17 & 0.136 & 0.062 & 0.181 \\
\hline 5 & 0.201 & 0.079 & 0.103 & 0.527 & 0.217 & 0.008 & 0.143 & 0.113 & 0.079 & 0.137 & 0.052 & 0.208 & 0.41 & 0.209 & 0.001 \\
\hline 6 & 0.229 & 0.095 & 0.124 & 0.332 & 0.228 & 0.006 & 0.129 & 0.052 & 0.219 & 0.125 & 0.081 & 0.103 & 0.446 & 0.114 & 0.065 \\
\hline 7 & 0.188 & 0.094 & 0.11 & 0.212 & 0.105 & 0.084 & 0.126 & 0.058 & 0.21 & 0.116 & 0.064 & 0.21 & 0.201 & 0.089 & 0.092 \\
\hline & $\begin{array}{l}\text { Rema } \\
1-\mathrm{G} \\
2-\mathrm{Re} \\
3-\mathrm{Al} \\
4-\mathrm{Al} \\
5-\mathrm{Ul} \\
6-\mathrm{Al} \\
7-\mathrm{Fe}\end{array}$ & $\begin{array}{l}\text { seral sel } \\
\text { sistance } \\
\text { ility of e } \\
\text { ility of a } \\
\text { yielding } \\
\text { ility of } d \\
\text { ding not }\end{array}$ & $\begin{array}{l}\text { failur } \\
\text { pressin } \\
\text { king fo } \\
\text { mandir } \\
\text { uilty }\end{array}$ & $\begin{array}{l}\text { ce } \\
\text { and cr } \\
\text { feeling } \\
\text { favou }\end{array}$ & cism & & & & & & & & & & \\
\hline
\end{tabular}

After identification if social competence can by emplpyed to forecast the perceived creativity of students, the regression analysis was applied. It allowed foreseeing prognostic possibilities of dependent variables in the regression equation on the basis of independent variables. The results of linear regression analysis disclose a prognostic meaning of social competence to expression of perceived creativity. Thus, on the basis of social competence the expression of person's perceived creativity can be significantly forecasted. Following the data of regression analysis, considering the specifics and links of correlation between social competence and perceived creativity and after evaluation and identification of social competence-based prognostic possibilities of perceived creativity, it can be assumed that a more targeted choice of methods, forms and assignments for development of students' social competence, the expression of their perceived creativity is also promoted. However, it should be noted that the percentage of dispersion of person's social competence and perceived creativity, explained through regression, is not high. This shows that social competence cannot serve as the only source for drawing unambiguous conclusions and foreseeing the level of students' perceived creativity. Therefore, adding other methods of information gathering, applying different research methodologies, increasing the sample, further research on the factors that allow forecasting the expression of students' perceived creativity with a higher probability and stronger prognostic power. 


\section{ENTREPRENEURSHIP AND SUSTAINABILITY ISSUES}

ISSN 2345-0282 (online) http://jssidoi.org/jesi/

2021 Volume 8 Number 3 (March)

http://doi.org/10.9770/jesi.2021.8.3(20)

\section{Conclusions}

1. The research results showed the strongest expression of self-confidence and resistance to failure and criticism among students. The lowest mean averages were identified in the three subscales: ability to demand, not feeling guilty and ability to ask for a favour.

2. Analysing the peculiarities of students' perceived creativity, the highest values were observed within the scales of pursuit of innovation and creativity, childishness and originality. The research results revealed that the lowest mean values of expression of perceived creativity were established within the scales of intuition and inversion.

3. Employing the Pearson correlation analysis, the correlations between the social competence and perceived creativity were evaluated and identified:

3.1. The identified significant correlations show that social profile students with a higher level of selfconfidence, unyielding, ability to express feeling and resistance to failure and criticism have a higher level of total creativity indicator. The indicator of the subscale of not feeling guilty negatively correlates with that of total creativity.

3.2. The correlation analysis discloses that self-confident students also posses a higher level of intuition, phantasy, pursuit of innovation, originality and criticism, whereas stronger expression of originality, criticism, phantasy, flexibility, pursuit of innovation and inversion is characteristic of students with more expressed unyielding.

3.3. The research allowed concluding that the students' resistance to failures and criticism positively correlates with the indicators of intuition, creativity, pursuit of creativity and innovation, flexibility, originality and criticism. The research participants with stronger ability to ask for a favour, tend to evaluate their originality and flexibility as well as pursuit of creativity higher.

3.4. The correlation analysis of subscales of perceived creativity and social competence disclosed positive relations between the subscales of the participants' ability to express feelings and creativity: flexibility, childishness, originality, criticism, pursuit of innovation and creation.

3.5. The results of correlation analysis revealed that students' ability to demand negatively correlates with childishness and positively correlates with criticism and pursuit of innovation. Meanwhile, such indicators of perceived creativity as phantasy and childishness show negative correlation with not feeling guilty and the latter positively correlates with the subscale of criticism.

4. The research results show that certain components of social competence acquire a prognostic meaning for expression of students' perceived creativity and allow for significant forecasting of students' perceived creativity.

\section{References}

Cropley, D. H. (2015). Promoting Creativity and Innovation in Engineering Education. Psychology of Aesthetics, Creativity, and the Arts, 9 (2), 161-171. https://doi.org/10.1037/aca0000008

Beaney, M. (2019). First Steps and Conceptual Creativity. Wittgenstein on Philosophy, Objectivity, and Meaning, 15, $119-142$.

Benea-Popuşoi, E., \& Duca, S. (2021). The Development of Human Creativity as a Way to Compete Globally and Make Knowledge Economy More Inclusive. Advances in Intelligent Systems and Computing, 1191, 676-686.

Broekhoven, K., Cropley, D., \& Seegers, P. (2020). Differences in Creativity Across Art and STEM Students: We are more alike than unalike. Thinking Skills and Creativity, 38 (100707), 1-13.

Camargo, A., Çelik, P., \& Storme, M. (2020). Cultural Self-efficacy Increases Creativity in Bicultural Dyads: Evidence From Two Dyadic Divergent Thinking Tasks. Thinking Skills and Creativity, 38 (100725), 1-10. 


\section{ENTREPRENEURSHIP AND SUSTAINABILITY ISSUES}

ISSN 2345-0282 (online) http://jssidoi.org/jesi/

2021 Volume 8 Number 3 (March)

http://doi.org/10.9770/jesi.2021.8.3(20)

Chen, S., Chandler, J., \& Venkatesh, A. (2018). The Influence of Objects on Creativity. Creativity and Innovation Management, 29, 481494. https://doi.org/10.1111/caim.12379

Csikszentmihalyi, M. (1996). Creativity. Flow and the Psychology of Discovery and Invention. New York: Harper Perennial.

Demarin, V., Derke, F. (2020). Creativity-the Story Continues: An Overview of Thoughts on Creativity. Mind and Brain: Bridging Neurology and Psychiatry, 1, 1-20.

Diković, M., \& Gergorić , T. (2020). Teachers' assessment of active learning in teaching Nature and Society. Economic ResearchEkonomska Istraživanja, 33(1,) 1265-1279, https://doi.org/10.1080/1331677X.2020.1728563

Elisondo, R. (2016). Creativity is Always a Social Process. Creativity.Theories-Research-Applications, 3 (2), $194-210$.

Farmer, S. M., Tierney, P., \& Kung-McIntyre, K. (2003). Employee Creativity in Taiwan: An Application of Role Identity Theory. Academy of Management Journal, 46 (5), 618-630.

Feist, G. J. (1998). A Meta-Analysis of Personality in Scientific and Artistic Creativity. Society for Personality and Social Psychology, 2 (4), p. 290-309. https://doi.org/10.1207/s15327957pspr0204_5

Fonseca, I., Bernate, J., Betancourt, M., Barón, B., \& Cobo, J. (2019). Developing Social Responsibility in University Students. ACM International Conference Proceeding Series, 28, 215-218.

Glăveanu, V. P. (2014). Distributed Creativity: Thinking Outside the Box of the Creative Individual. Springer.

Grakauskaite-Karkockienè, D. (2010). Training of Creativity: Theoretical and Practical Aspects. Educational Psychology, $21,66-74$.

Griffiths, C., \& Costi, M. (2020). The Creativity Thinking Handbook. Your Step-By-Step Guide to Problem Solving in Business. Kogan Page.

Haase, J., Hoff, E. V., Hanel, P. H. P., \& Innes-Ker, Å. (2018). A Meta-Analysis of the Relation between Creative Self-Efficacy and Different Creativity Measurements. Creativity Research Journal, 30 (1), 1-16, https://doi.org/10.1080/10400419.2018.1411436

Hemlin, S., Allwood, C. M., \& Martin, B. R. (2008). Creative Knowledge Environments. Creativity Research Journal, 20 (2), 196-210.

Hoyle, R.H. (2006). Personality and Self-Regulation: Trait and Information-Processing Perspectives. Journal of Personality, 74, 15071526 .

Huang, L., \& Luthans, F. (2015). Toward Better Understanding of the Learning Goal Orientation-Creativity Relationship: The Role of Positive Psychological Capital. Applied Psychology, 64 (2), 444-472.

Huertas, M. K. Z., \& Pergentino, I. (2020). The Effect of "Co-Creation with Consumers" Claims on Purchase Intention: The Moderating Role of Product Category Performance Information. Creativity and Innovation Management, 29 (S1), 75-89.

Hughes, D. J., Lee, A., Tian, A. W., Newman, A., \& Legood, A. (2018). Leadership, Creativity, and Innovation: A Critical Review and Practical Recommendations. The Leadership Quarterly, 29 (5), 549-569.

Iždonaitė-Medžiūnienė, I. (2009). Substantiation of Tourism management Students' Social Competence Modeling. Doctoral Thesis. Šiauliai.

Jahanshahi, A. A., Brem, A., \& Hoerauf, D. (2019). Employee Creativity in War Zones: Empirical Evidence from Small Firms in Afghanistan. Creativity and Innovation Management, 29, 465-480. http://doi.org/10.1111/caim.12396

Jaskyte, K., Taylor, H., \& Smariga, R. (2009). Student and Faculty Perceptions of Innovative Teaching. Creativity Research Journal, 21 (1), 111-116. 


\section{ENTREPRENEURSHIP AND SUSTAINABILITY ISSUES}

ISSN 2345-0282 (online) http://jssidoi.org/jesi/

2021 Volume 8 Number 3 (March)

http://doi.org/10.9770/jesi.2021.8.3(20)

Judge, T. A., \& Ilies, R. (2002). Relationship of Personality to Performance Motivation: A Metaanalytic Review. Journal of Applied Psychology, 87, 797-807.

Karimi, P., Rezwana, J., Siddiqui, S., Maher, M. L., \& Dehbozorgi, N. (2020). Creative Sketching Partner: An analysis of Human-AI Cocreativity. International Conference on Intelligent User Interfaces: Proceedings, IUI17, 221-230.

Kelemen, P., Born, E., \& Ondráček, T. (2020). Theorizing on the connection between organizational and individual mindfulness. Economic Research-Ekonomska Istraživanja, 33(1), 1813-1829, https://doi.org/10.1080/1331677X.2020.1761417

Khan, J., Malik, M., \& Saleem, S. (2020). The Impact of Psychological Empowerment of Project-Oriented Employees on Project Success: A Moderated Mediation Model. Economic Research-Ekonomska Istraživanja, 33(1), 1311-1329, https://doi.org/10.1080/1331677X.2020.1756374

Koh, D., Lee, K., \& Joshi, K. (2019). Transformational Leadership and Creativity: A Meta-Analytic Review and Identification of an Integrated Model. Journal of Organizational Behavior, 40 (6), 625-650.

Lekavičienė, R. (2001). Socialinès kompetencijos psichologiniai kriterijai ir vertinimai. Lietuvos studentų tyrimai [Psychological Criteria and Assessment of Social Competence: Lithuanian Students' Research: Monograph]. Kaunas: Vytautas Magnus University.

Liu, H., Bracht, E., Zhang, X., Bradley, B., \& Rolf van Dick, R. (2020). Creativity in Non-Routine Jobs: The Role of Transformational Leadership and Organizational Identification. Creativity and Innovation Management, 29 (S1), 1-15. https://doi.org/10.1111/caim.12419

Malinauskas, R. (2003). Influence of social Training on the Social Competence of Sport Pedagogues Pedagogy, 66, 44-50.

Newman, A., Neesham, C., Manville, G., \& Tse, H. H. (2018). Examining the Influence of Servant and Entrepreneurial Leadership on the Work Outcomes of Employees in Social Enterprises. International Journal of Human Resource Management, 29 (20), $2905-2926$.

Pacevičius, J. (2005). Emotional Correlates of the Basic Traits of Personality. Psychology, 31, 16-38.

Petrulis, V. (1988). Reflection of Creativity and Creative Productivity Among Scientists. Leningrad.

Pociūtè, B., Isiūnaitè, V. (2011). Problems of Career Choice and Personality Traits. Psychology, 43, 78-91.

Prabhu, V., Sutton, C., \& Sauser, W. (2008). Creativity and Certain Personality Traits: Understanding the Mediating Effect of Intrinsic Motivation. Creativity Research Journal, 20 (1), 53-66. https://doi.org/10.1080/10400410701841955

Rakauskaite, E. D. (2014). Development of Creativity - an Investment to the Creative Society. Social Technologies, 4 (2), $333-347$.

Rantanen, J., Metsapelto, R.L., Feldt, T., Pulkinnen, L., \& Kokko, K. (2007). Long-term Stability in the Big Five Personality Traits in Adulthood. Scandinavian Journal of Psychology, 48 (6), 511-518. https://doi.org/10.1111/j.1467-9450.2007.00609.x

Roskes, M., De Dreu, C. K. W., \& Nijstad, B. A. (2012). Necessity is the Mother of Invention: Avoidance Motivation Stimulates Creativity through Cognitive Effort. Journal of Personality and Social Psychology, 103 (2), 242-256, https://doi.org/10.1037/a0028442

Shafi, M., Lei, Z., Song, X., \& Sarker, M. N. I. (2020). The Effects of Transformational Leadership on Employee Creativity: Moderating Role of Intrinsic Motivation. Asia Pacific Management Review, 25 (3), 166-176. https://doi.org/10.1016/j.apmrv.2019.12.002

Šinkūnienè, J. R. (2011). Aspects of Creativity in Social Work. Social Work, 10 (1), 63 - 70.

Sipahi, E. (2018). Creativity and the Importance of Business Management. International Journal of Scientific \& Engineering Research, 8 (8), 428-439.

Šniras, Š. (2005). The Impact of Training Program on Competitive Social Skills of Basketball-Playing Schoolchildren. Education. Physical Education. Sport, 5 (59), 75-81. 


\section{ENTREPRENEURSHIP AND SUSTAINABILITY ISSUES}

ISSN 2345-0282 (online) http://jssidoi.org/jesi/

2021 Volume 8 Number 3 (March)

http://doi.org/10.9770/jesi.2021.8.3(20)

Song, W., Yu, H., Zhang, Y., \& Jiang, W. (2015). Goal Orientation and Employee Creativity: The Mediating Role of Creative Role Identity. Journal of Management \& Organization, 21(1), 82-97.

Sternberg, R. J. (2006). Creating a Vision of Creativity: The First 25 Years. Psychology of Aesthetics, Creativity, and the Arts, S (1), 2-12. https://doi.org/10.1037/1931-3896.S.1.2

Sung, S. Y., \& Choi, J. N. (2009). Do Big Five personality factors affect individual creativity? The Moderating Role of Extrinsic Motivation. Social Behaviour and Personality: an Interantional Journal, 37 (7), 941-956. https://doi.org/10.2224/sbp.2009.37.7.941

Torrance, E.P. (1986). Teching Creative and Gifted Learners. Handbook of research on teaching In M. C. Witrock (Eds.), 630-647. New York: Macmillan.

Tse, H. H., To, M. L., \& Chiu, W. C. (2018). When and Why does Transformational Leadership Influence Employee Creativity? The Roles of Personal Control and Creative Personality. Human Resource Management, 57 (1), 145-157. https://doi.org/10.1002/hrm.21855

Vaičiūnienè, V., \& Mažeikienè, V. (2014). Creativity, Networked Learning/Teaching and the Development of Deeper Cognitive Skills in University Studies. Societal Studies, 6 (1), 21-33.

Vaitkevičius, R., \& Saudargienè, A. (2006). Statistics with SPSS in Psychological Research: A Textbook. Kaunas: VDU.

Wang, N., Jome, L. M., Haase, R. F., \& Bruch, M. A. (2006). The Role of Personality and Career Decision-Making Self-efficacy in the Career Choice Commitment of College Students. Journal of Career Assessment, 14, 312-332. https://doi.org/10.1177/1069072706286474

Wang, P. (2020). Core Job Characteristic and Uncertainty Avoidance: Into the Black Box of Transformational Leadership Effect on Creativity. The Journal of Creative Behavior, 54 (2), 311-322. https://doi.org/10.1002/jocb.367

Wang, S., Li, R., Ma, D., \& Gao, H. (2019). The Effects of Individual Preparations on Group Creativity. ACM International Conference Proceeding Series, 28, 219-222.

Wolfradt, U., \& Pretz, J. E. (2001). Individual Differences in Creativity: Personality, Story Writing, and Hobbies. European Journal of Personality, 15, 297-310. https://doi.org/10.1002/per.409

Kristina SAMAŠONOK, Doctor of Social Sciences (Educology), Docent of the Faculty of Business Management of Vilniaus kolegija/University of Applied Sciences, Didlaukio g., 49, Vilnius, tel. (8-5) 2191640, Faks. (8-5) 2191639, el. p. administracija[eta]vvf.viko.lt; research interest areas: social exclusion risk for adolescence adaptation, institutional development and adaptive behaviour modelling, the first year students' adaptation to the study process, motivation factors for choosing studies, developing students' creative thinking in a higher school.

ORCID ID: https://orcid.org/0000-0002-8985-6942

Agnė JUŠKEVIČIENĖ, Doctor of Social Sciences (Educology), Docent of the Faculty of Business Management of Vilniaus kolegija/University of Applied Sciences, Didlaukio g., 49, Vilnius, tel. (8-5) 2191640, Faks. (8-5) 2191639, el. p. administracija[eta]vvf.viko.lt; research interest areas: inclusive, multicultural education in higher and general education school, acquisition and development of general and subject competencies, formation of identity in adolescence.

ORCID ID: https://orcid.org/0000-0001-9732-8616

Make your research more visible, join the Twitter account of ENTREPRENEURSHIP AND SUSTAINABILITY ISSUES: @Entrepr69728810

Copyright (C) 2021 by author(s) and VsI Entrepreneurship and Sustainability Center

This work is licensed under the Creative Commons Attribution International License (CC BY).

http://creativecommons.org/licenses/by/4.0/

c) (7) Open Access 